\title{
THE ADDED VALUE OF REGENERATIVE ARCHITECTURE AND CONTEMPORARY AESTHETIC PHILOSOPHY
}

A B S T R A C T

Regenerative architecture seeks to impact positively on the environment. It aims to produce buildings that reduce the degenerative consequences of human activity and add positively to the environment. To add value, in dimensions such as beauty, included in the design approaches of regenerative architecture, and in, for example, the Living Building Challenge, where the biophilic and biomimetic are raised as aspirations, however, poses some fundamental questions for the ways of thinking that underlie regenerative architecture and the discipline of architecture. Design tools suggest that the "greater than character" can be determined, measured even, in all categories, but aspirations also call for radical changes to the way we see and understand human lives. Understandings of aesthetics and the primacy of a sensory connection with the environment are little acknowledged questions within the philosophy of regenerative design outside the suggestion of biophilia. In this paper, I examine the foundations of environmental aesthetics: stories, myths, dreams and the importance of the creative imagination in understanding and reevaluating the way we see and understand human lives and our relationship to our built and natural environments.
Andrea Wheeler

Iowa State University

andrea1@iastate.edu
KEY WORDS

SUSTAINABLE

REGENERATIVE

INANNA

GODDESS

AESTHETICS

PHILOSOPHY

ARCHITECTURE

THEORY

DESIGN

FEMINISM 


\section{INTRODUCTION}

At the heart of regenerative design is a challenge to understand its ability to impact positively on the environment and to be able to evaluate its additive sum character. Regenerative architecture aims to design buildings that reduce their negative impact on the environment. Raymond Cole writes that regenerative architecture aims to 'reduce the degenerative consequences of human activity on the health and integrity of ecological systems. ${ }^{1}$ This positioning as better than (a qualitative measure) or "greater than" (a quantitative measure) - as additive rather than subtractive - raises a question, nevertheless, about the real condition against which such added value is measured.

Widely different interpretations of what sustainable architecture is exist within the sustainability movement. Interpretations stretch from those governed by conservative perspectives to radical approaches calling for social transformation, and this means that evaluating regenerative architecture also requires reconciling what Cole sees as 'widely different interpretations of value and value-adding that exist within the sustainability movement'. ${ }^{2}$

The regenerative approach to architectural design has a broad base of concern, and aesthetics are included. This includes the aesthetic dimension, and regenerative philosophy in design directs architects towards biophilic or biomimetic approaches as those attributed to have the most positive impact. However, in the performance-dominated, engineering-heavy field of sustainable architecture, the politics of aesthetics have been neglected. While sustainable designers propose finding new ways to live, few scrutinise aesthetics as encompassing the aspiration to find new ways to live.

In this paper, I thus examine sustainable design theory that diverts attention away from the sensual; and secondly, I examine how regenerative architecture might be conceived as mode of sensory inquiry. The intention, in all these sections, is to think in part outside traditional understandings of regenerative design, and to include in this an examination of the aesthetic dimension.

\section{THE POSITIVE SUM IMPACT OF REGENERATIVE ARCHITECTURE}

Regenerative architecture adds more to an environment than it takes away. Its sum impact is positive. Chrisna du Plessis states that the paradigm that underlies the approach is one that calls for radical changes to structures of society, but at the same time, allows for the conceptualisation of this "greater than" character 
because it adopts a world view that 'sees nature as machine, understood and managed by reducing it to its parts'. ${ }^{3}$ The additive quality appears to us as a quantitative measure but what is radically aspirational in intention may not easily be measurable.

Before such exploration, I would like to take a detour from the path to delve deep into this regenerative quality. I would like to present a story. Stories can touch us subtly and my motive, here, is to evoke a connection to some sense on the periphery of our vision, in the liminal spaces of our thinking and feeling. The story is of Inanna, the goddess of heaven and earth: a Sumerian goddess and a goddess of one of the first known cultures.

Symbols of the goddess present a resistance to male privilege, but Inanna's story is more than a simple resistance. She has strength and cultural skills. She has an independent will. She is not a passive and receptive female character of patriarchal myth, and yet her strength acts not to overcome rule, not to resist progress, or to resist logos modes of thinking (logic and reason). ${ }^{4}$ She shares the knowledge found in her journey with the male gods and it changes them and their rule. It was her own decision to explore prohibited spaces outside of her culture. Inanna's story is a demand for recognition as an equal, in her new understanding of life. Inanna's story is about a passion for an exploration of life itself and this meant a descent into the underworld and inevitable death, but from which she returned. She is a goddess of regeneration.

Diane Wolkstein and Samuel Noah Kramer describe all the written stories of Inanna as stages of life. In youth, for example, the young Inanna, leaning against the apple tree "rejoicing her vulva, wonderous to behold," as the prose states, and calls out: "I the queen of heaven, will visit the god of wisdom," and she sets out, by herself, to Enki, the god of wisdom and a creative, sculptor god. He was an inventor and an improviser; a problem solver. He was called an "image fashioner" and the "god of the original form, archetype." $\mathrm{He}$ was not especially bound by obedience to the other patriarchal gods and this makes him occupy, like Inanna, the space between an old (patriarchal order) and a new social and environmental relationship.

He was a god flowing with life, and with creative energy, and Inanna sought him out. The story says that beguiled by Inanna, and in a drunken state, Enki gave her the "Me"; that is to say, he gave her all of Sumerian culture, all the laws of heaven and earth, all the ordering principles and potencies, rites of civic society, all the skills and talents. He gave the young Inanna all his creator-god knowledge. She sings: 
He gave me the high priesthood... He gave me the art of forthright speech. He gave me the art of slanderous speech... He gave me the art of the hero. He gave me the art of power... He gave me the secure dwelling place... He gave me the craft of the woodworker... copperworker... scribe... smith... leather maker... fuller... builder... reed worker. ${ }^{7}$

Enki gave Inanna the art of Sumerian culture, and the story continues: "Then Inanna standing before her father [the moon] acknowledged the me Enki had given her."

However, in her more mature search, she casts off these forms of culture given to her by the god to understand life beyond the gods' rules and creations. Inanna, in her descent into the underworld, wanted knowledge of what was real and what was life. The realm was forbidden by the gods: she wanted to feel and to witness-with her sister (the goddess of death), her grief for the death of her husband. ${ }^{9}$

Inanna's decent to the underworld was her decision: "The goddess opened (set) her ear, her receptor for wisdom, to the Great Below." ${ }^{10}$ Inanna decided to go into the underworld and was condemned to death, but Enki saved her, brought her back, regenerated her, (the only god to offer help) sending messengers made of dirt, carrying the food and water of life to revive her and allow her escape.

Inanna's story, which is expressed here all too briefly, is about a desire to understand living beyond what is known or permitted to be known in the existing system; to be able to travel outside the frame of contemporary cultures (or the me). Her stories tell us to listen to a different way of knowing, to "see" differently, imperfect ways perhaps, or just different ways. Like many other different approaches that could be suggested to us as a different manner of understanding living: she "sets her ear".

For the psychoanalyst Sylvia Brinton Perera, the myth holds a pattern of seasonal transformation and rebirth that has a psychological connection. Perera writes of Inanna:

She represents the liminal, the intermediate regions, and energies that cannot be contained or made certain and secure. She is not the feminine as night, but rather she symbolises consciousness of transition and borders, places of intersection and crossing over that imply creativity and change and all the joys and doubts that go with human consciousness that is flexible, playful, never certain for long. ${ }^{11}$ 


\section{REgENERATIVE ARCHITECTURE, POLITICAL AESTHETICS - A NEW THEORETICAL DIVERSION}

To return, then, there are three philosophers that I would like to draw on to explore further this "eye" on a regenerative aesthetic: Jacques Rancière, for his political aesthetics - a human right for all that in its freedom spills over into a criticism of social, environmental and economic conditions; ${ }^{12}$ Gernot Böhme, for his architectural aesthetic of atmosphere - a sensory aesthetic most appropriate for architecture; ${ }^{13}$ and Luce Irigaray, a philosopher and feminist, for her new human ${ }^{14}$ - born with its own will to live, (but unrecognised) and that demands an environment in which to grow and develop freely. ${ }^{15}$

Rancière's early academic publications looked to the journals of artisans and poets, and books that eluded history, to discover historical perspectives that had not always been seen. ${ }^{16}$ For Rancière, these were works of authors whose views were equally as valid as any other more traditional record of history. From the beginning his work was an engagement with understandings of equality. The people he acknowledged were not naïve, or ignorant. Their stories were neither inferior, nor illustrative of a lesser knowledge. In the Ignorant Schoolmaster, for example, he argues for just this, for a levelling of knowledge in a new educational community: 'One based on undoing the rigid stratification of scholars and their knowledge - a kind of levelling at the top - and the creating of a convivial, open, more egalitarian atmosphere in the schools. ${ }^{17}$ Rancière was dismantling the inequality between a teacher and student.

Dismantling the distinctions made between the world of art (available only to those educated in taste) and an art of everyday life - between the traditions of the avant-garde and the aestheticization of common existence (or life) and in the "setting of our ear" (the attitude or approach of Inanna) to life - is potentially socially and environmentally transformative. The aesthetic dimension in life, and the staging of this experience, Rancière argues, can revolutionise life.

The philosophy of Rancière aims to reframe our aesthetic experience, where politics and everyday affect share the same space: '...the original scene of aesthetics,' he argues, 'reveals a contradiction that is not the opposition of art versus politics, high art versus popular culture, or art versus the aestheticization of life'. ${ }^{18}$

Preconceptions abound, and aesthetics is fraught with concerns about seduction and the "marketing" of sustainability. In the aesthetic experience, however, for Rancière, art and the spectator are caught up in a specific sensorium, cancelling 
the oppositions of activity and passivity. In this free play, art understood as being without practical function, and art of the revolutionary, are not counterposed, and this scene or plot, he argues '.. promises a still unheard-of state of equality'. ${ }^{19}$ However, being "political" in this context, also carries ambiguities. This is both political and non-political:

'Aesthetic art promises a political accomplishment that it cannot satisfy, and thrives on that ambiguity. That is why those who want to isolate it from politics are somewhat beside the point. It is also why those who want it to fulfil its political promise are condemned to a certain melancholy. ${ }^{20}$

Rancière's political aesthetics are not developed with the same attention by other aesthetic philosophers but, he is not necessarily discussing architecture. By contrast, Böhme, a contemporary German philosopher, links it with architecture in his theory of atmosphere. The theory of atmosphere is the only aesthetic theory appropriate for architecture, he argues. ${ }^{21}$ For Böhme, architecture has to be understood as sensory experience and as a co-production of experience between a subject and the environment. Architectural atmosphere is "felt" (but there is here no distinction between thinking and feeling in the lived-felt-body). His work on an ecological aesthetics adopts this same approach of co-production, challenging our usual understanding of lived bodies in the environment. Nature is ahead of us, to be co-constructed and reconstructed forever in our aesthetic expression. Our understandings of nature (and perhaps we could also say of life) are to be created in our stories and in our regenerative architectures.

Irigaray, critical of current environmental debates and arguing that they separate thinking from living. She argues that before any ecological deliberation 'it would be advisable to wonder about what being alive signifies, and whether we are really living, or how we could be or become living'. ${ }^{22}$

This is a discovery, but not as rediscovered truth of an original way of thinking and feeling about life. One of our strongest cultural motives, Irigaray argues, is this search for origin seen in academic research, philosophy, art and also in the background to theories of sustainable design. This motive for the disclosure of origin - as a foundation upon which to construct something new - is of a patriarchal societal construction. It is an equal and different relationship between two humans that goes unrecognised in philosophical traditions and patriarchal cultures. The search for original ways of feeling and thinking are symptoms of patriarchal cultures. Recognising the incompatibility of such a search with the aesthetic construction of new notions of the human being could 
free humans from the desire always for (re)connection with a refound origin, and from the seduction of affect: nothing has been lost, so nothing is to be regained. In this way desire towards excessive consumption could be mitigated.

Discussions in sustainable design condemn aesthetics because they are based upon the artificial distinction of seeing and doing, but sustainable design as mode of inquiry calls upon us to journey outside traditional understandings of living to give up the security of (patriarchal) logos, the security of (mathematical) reasoning, to adopt some imperfect ways of thinking. Stories can help us to draw connections. Stories can illustrate particular complications in living, but stories also level the storyteller and listener. Inanna's stories are those of her own rights and responsibilities in life in a world otherwise full of artificial "oughts" and "should". She has choice and the will. She brought her own gifts, adding to the "me" given to her by Enki: 'She brought allure. She brought the art of women. She brought the perfect execution of the me. ${ }^{, 23}$

\section{CONCLUSION}

To return (and Inanna did return from the underworld) to regenerative architecture, and to its character, that is to say, to give more back than is taken from the environment: the role of aesthetics takes on a new fascinating intent towards liberation. The additive character of regenerative architecture could be described as an approach giving back to logos by "setting an ear" to what lies outside our reason; to what it means to live, to die and to be reborn with new knowledge. This would be a continuous and changing movement: the intention of an ecological aesthetic and thus the discovery of a perspective very different to rational approaches to sustainable or regenerative design or to the attribution of a calculable positive impact.

The ecological aesthetic of the regenerative architecture could also be the addition of the "eyes of life", ${ }^{24}$ seeking to see through values that are false, and beyond what is good or bad, to what is before judgement. This may not be an aesthetic that is validated by the collective, ${ }^{25}$ but it would be a fresh perspective, full of affect and full of the creative intention of a never-ending exploration. ${ }^{26}$ Perera writes that the current order fears it, because: 'It is crude, chaotic, surprising, giving a view of the group below ethics and aesthetics and the opposites themselves: It is the instinctual eye - an eye of the spirit in nature. ${ }^{27}$ Inanna's fate, as Perera writes, is that she must see the limits of the fathers and be witness to what was repressed. ${ }^{28}$ 
John Robinson and Raymond J. Cole, "Theoretical underpinnings of regenerative sustainability," Building Research \& Information 43, no. 2 (2015): 133.

Idem, 132.

Chrisna Du Plessis, "Towards a regenerative paradigm for the built environment," Building Research \& Information 40, no. 1 (2012): 8.

Sylvia Brinton Perera, Descent to the goddess: A way of initiation for women. No. 6. (Inner City Books, 1981), 30

Diane Wolkstein, Samuel Noah Kramer and Elizabeth Williams-Forte. Inanna, queen of heaven and earth: Her stories and hymns from Sumer (New York: Harper \& Row, 1983), 12.

Idem, 123.

Idem, 16-20.

Idem, 16.

Idem, 55.

Kramer Wolkstein and Williams-Forte, Inanna, queen of heaven and earth, xvii. 
Perera, 16

Jacques Rancière, The ignorant schoolmaster. Vol. 1. (Stanford, CA: Stanford University Press, 1991), viii (translators note).

Gernot Bohme, Atmospheric Architectures: The Aesthetics of Felt Spaces (London, New York: Bloomsbury, 2017).

Irigaray, Luce To Be Born: Genesis of a New Human Being (London: Palgrave, Macmillan)

Idem., 103.

Rancière, The Ignorant Schoolmaster, xix.

Idem, xiii.

Jacques Rancière, "The Aesthetic Revolution and Its Outcomes," Log, No. 22. The Absurd (Spring/ Summer, 2011): 20. Available at: http://www.jstor.org/stable/41765703.

Ibid.

Idem., 21.

Gernot Böhme, "Atmosphere as the subject matter of architecture," (Herzog \& DeMeuron: Natural History, 2006), 398-407.

Emily Anne Parker, "Interview[with Luce Irigaray]: Cultivating a Living Belonging," Journal of the British Society for Phenomenology 46, no. 2 (2015): 109.

Perera, Descent to the goddess, 26.

Idem, 32-33.

Idem, 34 .

Ibid.

Idem, 33.

Idem, 52. 
Böhme, Gernot. "Atmosphere as the subject matter of architecture." Herzog \& DeMeuron: Natural History (2006): 398-407.

Böhme, Gernot. Atmospheric architectures: The aesthetics of felt spaces. London: Bloomsbury Publishing, 2017

Du Plessis, Chrisna. "Towards a regenerative paradigm for the built environment." Building Research \& Information 40, no. 1 (2012): 7-22.

Irigaray, Luce. To be born: Genesis of a new human being. New York: Springer, 2017.

Kramer, Samuel Noah, and Diane Wolkstein. Inanna, Queen of Heaven and Earth: Her Stories and Hymns from Sumer. New York: Rider, 1983.

Parker, Emily Anne. "Interview: Cultivating a Living Belonging." Journal of the British Society for Phenomenology 46, no. 2 (2015): 109-116.

Perera, Sylvia Brinton. Descent to the goddess: A way of initiation for women. Toronto: Inner City Books, 1981.

Ranciere, Jacques. "The aesthetic revolution and its outcomes." $\log 22$ (2011): 16-21.

Rancière, Jacques. The ignorant schoolmaster. Vol. 1. Stanford, CA: Stanford University Press, 1991.

Robinson, John, and Raymond J. Cole. "Theoretical underpinnings of regenerative sustainability." Building Research \& Information 43, no. 2 (2015): 133-143. 
STEREOTIP LEPOTE I IZGRADNJE. ESTETIKA ARHITEKTURE.

\section{Raffaele Milani}

U ovom radu smo se bavili stereotipom kao otpornim modelom tipova stvorenih objekata, slikom proizvodnog procesa koja se ponavlja ili se može ponavljati i standardizovanim modelom virtuelnosti; drugim rečima, stereotipizacija daje formu stvarima unutar sistema objekata koji se serijski reprodukuju. Viševekovna sinteza zanatstva i materijala se u našem vremenu transformisala u dizajn. Rekonstrukcija objekta podrazumeva praćenje tehnika koje su korišćene u nastanku istog, uključujući i one tradicionalne. U pogledu odnosa medju tehnologijama, vodi se žestoka rasprava izmedju onih koji žele da brane tragove prošlosti kao sećanje koje je značajno za budućnost, kao i instrument za harmonizaciju masa, i onih koji u potpunosti favorizuju novitete hibridnog stila koji je u modi posle faze modernizma. Ovi drugi podržavaju deregulaciju proizvodnje arhitektonskih objekata i nekoherentnu, improvizovanu organizaciju prigradskog okruženja. Tokom istorije su postojale značajne razlike u mišljenju o vrednosti čovečanstva, kvalitetu života, načinima razmišljanja i oblicima kulture i umetnosti.

KLJUČNE REČI: ESTETIKA, ARHITEKTURA, UMETNOST, JEZIK, STEREOTIP, ETIKA, LEPOTA

\section{MULTIKRITERIJUMSKA PROCENA LEPOTE U ARHITEKTURI \\ Boguslaw Szuba}

Članak se bavi problemima lepote u arhitekturi koji se nalaze u raznim slojevima značenja koji se odnose na: $\left(^{*}\right)$ kreativnu ideju planirane investicije; $(*)$ sposobnost da se odredi pravo mesto za planiranu investiciju, uskladjujući arhitekturu u prostoru lokacije, sa posebnim osvrtom na prirodno okruženje; $(*)$ komunikaciju i informacije sa okolinom; $(*)$ poštovanje tradicije i običaja koji se poštuju u lokalnom socijalno-kulturnom okruženju, obraćajući pažnju na istorijski kontinuitet i koherenciju arhitektonskih oblika koji se koriste; $\left(^{*}\right)$ kreativnost oblikovanja prostora; (*) preciznost i inovativnost funkcionalnih i korišćenih prostornih rešenja; $\left(^{*}\right)$ partnerski odnos sa susedstvom; $\left(^{*}\right)$ široko shvaćeno učešće u procesu investiranja; $\left({ }^{*}\right)$ davanje značenja pokrećući filozofsku poruku i transcendenciju; $(*)$ pravilno korišćenje i upravljanje; $(*)$ postizanje socijalnih i kulturnih ciljeva; $(*)$ sposobnost planiranja transformacije / revitalizacije postojećih arhitektonskih objekata.

Istraživačka metoda je analiza navedenih komponenti na osnovu izvora iz literature i primera arhitektonskih objekata ili urbanih kompleksa.

Razmatranja vode do teze: Lepota u arhitekturi je stanje harmonije estetskih i upotrebnih vrednosti oblikovanog prostora u odnosima kreativnog odgovora na široko shvaćene uslove lokalnog, prirodnog, socijalno-kulturnog i izgradjenog okruženja.

KLJUČNE REČI: LEPOTA U ARHITEKTURI, KRITERIJUMI LEPOTE U ARHITEKTURI, HARMONIJA ARHITEKTURE I OKRUŽENJA, FILOZOFIJA ARHITEKTURE, ESTETIKA ARHITEKTURE

\section{ARHITEKTURA KAO INSTRUMENT ESTETSKE I POLITICKE MISLI Thomas SYMEONIDIS}

Uprkos uobičajenom pristupu arhitekture u smislu zamisli, dizajna i izgradnje izgradjenog okruženja, u ovom radu ističemo da se arhitektura može koristiti kao instrument estetske i političke misli. Zbog toga se oslanjamo na definicije arhitekture ističući ili njene aspekte principa (arché) ili konstrukcije ili njen relacijski karakter. S tim u vezi, arhitektura će se koristiti kao sredstvo za pitanja konceptualizacije i promišljanja na preseku dve ključne tačke političke teorije - jednakosti i pravde. 
Glavna hipoteza je da se u savremenom estetskom režimu misao o estetici ne može razlikovati od politike čime se podržavaju glavni aspekti relevantnih doprinosa Žaka Ransiera (Jacques Rancière). U ovoj analizi počinje se sa prikazivanjem srodnosti izmedju političke i estetske misli, a zatim se razradjuju aspekti arhitekture kao skale, tipa, oblika, dijagrama, istorije i hijerarhije kako bi se prikazalo funkcionisanje arhitekture kao instrumenta misli. U tom cilju prikazana je čvrsta shema i definicija misli u savremenoj filozofiji.

Uspostavljanjem analogija izmedju procesa misli i procesa arhitekture, na kraju će se pokazati da se arhitektura može koristiti na obrnuti način tako da se istaknu pitanja estetske i političke teorije i prakse.

KLJUČNE REČI: ESTETIKA, ARHITEKTURA, DIJAGRAM, ŽAK RANSIER, POLITIČKA TEORIJA, ODNOS, MISAO

\section{DODATA VREDNOST REGENERATIVNE ARHITEKTURE I FILOZOFIJE SAVREMENE ESTETIKE}

\section{Andrea Wheeler}

Regenerativna arhitektura teži da pozitivno utiče na okruženje. Njen cilj je da proizvede objekte koji umanjuju degenerativne posledice ljudske aktivnosti, a koje pozitivno utiču na životnu sredinu. Da bi se dodala vrednost, u dimenzijama kao što je lepota, uključena u projektne pristupe regenerativne arhitekture i, na primer, Living Building Challenge, gde se biofilija i biomimetika postavljaju kao aspiracija, s druge strane, postavljaju se neka osnovna pitanja vezana za načine razmišljanja koji predstavljaju osnovu regenerativne arhitekture i discipline arhitekture. Instrumenti projektovanja sugerišu da se ,više od karaktera“ može odrediti, čak i izmeriti u svim kategorijama, ali aspiracije takodje zahtevaju radikalne promene načina na koji posmatramo i razumemo život ljudi. Razumevanje estetike i primat senzorne povezanosti sa okolinom pitanja su koja nisu puno priznata u filozofiji regenerativnog dizajna izvan sugestije biofilije. Ovaj rad se bavi istraživanjem osnova estetike okoline: pričama, mitovima, snovima i značajem kreativne zamisli u shvatanju i ponovnom vrednovanju načina na koji posmatramo i razumemo ljudske živote i naš odnos prema izgradjenoj i prirodnoj sredini.

KLJUČNE REČI: ODRŽIVO, REGENERATIVNO, INANA, BOGINJA, ESTETIKA, FILOZOFIJA, ARHITEKTURA, TEORIJA, DIZAJN, FEMINIZAM

OD POZNATOG DO MISTERIOZNOG.

ESTETIKA ATMOSFERA U DOMAĆIM PROSTORIMA

\section{Elisabetta Di Stefano}

Pojam „poznatog“ je nedavno postao ključan u debati koja je pokrenuta u „Svakodnevnoj estetici“ (Everyday Aesthetics). U ovom eseju ću istražiti ovaj koncept u teorijama Arto Hapala (Arto Haapala) i Juriko Saito (Yuriko Saito), a zatim ću ispitati pojam poznatog - i nekih antonimskih pojmova (tj. čudno, misteriozno, strano) - prihvatajući fenomenološki pristup. Pozivajući se na teoriju atmosfera nemačkog fenomenologa Gernota Bohmea (Gernot Böhme), moj rad poredi pojam staklene kuće, o kom je bilo reči u modernističkoj teoriji, i pojam kuće školjke, koji su iz različitih perspektiva posmatrali Valter Benjamin (Walter Benjamin), Gaston Baselar (Gaston Bachelard) i Juhani Palasma (Juhani Pallasmaa). Na kraju ću povući paralelu sa pojmom čudnog koje se možda pretvara u ideju misterioznog ili stranog, na primer kada se providnost stakla koristi kao alat za kontrolu ili kada je ono ugrađeno u digitalne ekrane hipertehnoloških domova.

KLJUČNE REČI: ESTETIKA ARHITEKTURE, SVAKODNEVNA ESTETIKA, ČUDNO / POZNATO, STAKLENA KUĆA, HIPERTEHNOLOŠKE KUĆE, MODERNIZAM 